\title{
CHARACTERIZATION AND LYTIC ACTIVITY OF PSEUDOMONAS FLUORESCENS PHAGES FROM SEWAGE
}

\author{
Ananthi Radhakrishnan ${ }^{1}$, Ananthasubramanian $\mathbf{M}^{2^{*}}$ \\ ${ }^{1}$ Department of Biotechnology, PSG College of Technology, Coimbatore, India; ${ }^{2}$ Corresponding Author: Ananthasubramanian.M, \\ Associate Professor, PSG College of Technology, Coimbatore, India.
}

Submitted: December 04, 2010; Returned to authors for corrections: May 12, 2011; Approved: August 30, 2011.

\begin{abstract}
Pseudomonas fluorescens phages from sewage were tested against P. fluorescens isolates of soil and sewage. The phages were characterized as to host range, morphology, structural proteins and genome fingerprint. Of the seven phages isolated, one was found to be abundant in sewage $\left(5.9 \times 10^{7} \mathrm{pfu} / \mathrm{mL}\right)$, having broad host range, and distinct protein and DNA profile when compared to the other six phages. DNA restriction and protein profiles of the phages and their morphology indicate the diversity in the sewage environment. None of the isolates from the rhizosphere regions of various cultivated soils were susceptible to phages isolated from sewage.
\end{abstract}

Key words: Pseudomonas fluorescens, phages, RFLP, AFM, Protein analysis.

\section{INTRODUCTION}

Pseudomonas fluorescens is a diverse community of bacteria, found in wide range of habitats including soil, water and in industrial environments (34). Bacteriophages, the most abundant life forms on earth play major roles in bacterial ecology, adaptation to novel environments, and in bacterial evolution and pathogenesis $(23,10)$. They have shown good sensitivity and specificity in detecting bacterial pathogens (15). In soil environment $P$. fluorescens is known to improve plant growth and health. $(8,17,24)$. P. fluorescens phages are thought to be ecologically important in controlling bacterial number and activity, affecting composition and diversity of beneficial bacterial populations thereby affecting agricultural productivity. Earlier studies have reported isolation of fluorescent Pseudomonas phages from different environments $(1,5,9)$. According to the first ever global survey of wastewater irrigation untreated sewage is used to irrigate 10 percent of the world's crops. Sewage should be treated to remove pathogens to make it safe for irrigation (33). This study reports the diversity of $P$. fluorescens phages in sewage with reference to genome size, host range, structural proteins and morphology and their lytic activity on soil bacteria.

\section{MATERIALS AND METHODS}

\section{Sample Collection}

Sewage sample was obtained from the inlet of the sewage treatment plant located in Sulur, Coimbatore, India. The samples were immediately transported to the laboratory in 
collection bottles within $2 \mathrm{hrs}$ and kept at $4{ }^{\circ} \mathrm{C}$ prior to processing. The samples were clarified by filtration through cheese cloth and used for further analysis. Soil samples were collected at the depth of $2 \mathrm{~m}$ from the cultivated lands nearby the sewage treatment plant and stored at $4^{\circ} \mathrm{C}$.

\section{Isolation of bacteria from soil and sewage}

One $\mathrm{mL}$ of sewage sample was added to $9 \mathrm{~mL}$ sterile water which makes $10^{-1}$ dilution and subsequently diluted up to $10^{-6}$. Serial dilutions of soil samples were also prepared by adding one gram of soil into $9 \mathrm{~mL}$ of sterile water $\left(10^{-1}\right.$ dilution) and dilutions were made up to $10^{-6}$. The diluted samples were plated on King's B agar medium and incubated at $30^{\circ} \mathrm{C}$ for 48 hrs. Distinct colonies showing fluorescence under UV light at $360 \mathrm{~nm}$ were picked and streaked on KB agar medium to check the purity.

$P$. fluorescens isolated from sewage and from each of the twelve soil samples were subjected to biochemical tests as reported earlier Goszozynska et al (12) and Pickett et al (28). P. fluorescens MTCC 103 and P.aeruginosa MTCC 2474 were used as a referral strains. The bacterial cultures were grown at $30^{\circ} \mathrm{C}$ and $42^{\circ} \mathrm{C}$ with King's B agar medium.

\section{Bacteriophage isolation}

$P$. fluorescens phages isolated from sewage with sewage bacterial isolate as host was enriched by the modified method of Smith and Huggins (35). Briefly, $50 \mathrm{~mL}$ of LB broth and 50 $\mathrm{mL}$ of tryptone broth were added to $150 \mathrm{ml}$ of the sewage water and incubated for $1 \mathrm{hr}$ at $30^{\circ} \mathrm{C}$. To this $5 \mathrm{ml}$ of $24 \mathrm{hr} P$. fluorescens broth culture was added and grown for 16 hours at $30^{\circ} \mathrm{C}$. After centrifugation the supernatant was filtered through $0.22 \mu \mathrm{m}$ membrane filter and stored at $4{ }^{\circ} \mathrm{C} .100 \mu \mathrm{l}$ of diluted lysate mixed with $100 \mu$ l of overnight bacterial culture were mixed with $0.7 \%$ tryptone soft agar and overlaid on hard agar and plaque forming units (PFU) were observed after incubated overnight at $30^{\circ} \mathrm{C}$. Isolated plaques were pooled and concentrated using PEG (8000) precipitation method (30).

\section{Susceptibility Analysis}

Phage host range was examined using the spot test method (3). Soft agar (3-5 mL) with $100 \mu \mathrm{l}$ of an overnight bacterial culture and equal volume of $\mathrm{CaCl}_{2}(300 \mathrm{mM})$ were gently vortexed and spread on the surface of hard agar. Single drops of each phage lysate were spotted on the inoculated hard agar plates, and the plates were incubated overnight at $30^{\circ} \mathrm{C}$.

\section{Phage DNA isolation}

Phage DNA was extracted as reported earlier (16). Briefly, $0.5 \%$ of SDS and proteinase $\mathrm{K}(0.05 \mathrm{mg} / \mathrm{mL})$ were added to $0.5 \mathrm{ml}$ of phage lysate and heated for $15-30$ minutes in a $65^{\circ} \mathrm{C}$ water bath. A 1:1 phenol:chloroform extraction was performed 4 times followed by incubation with $0.3 \mathrm{M}$ Sodium acetate and 3 volumes of $100 \%$ cold ethanol at $-20^{\circ} \mathrm{C}$ for 30 minutes. Then $70 \%$ ethanol wash was performed 3 times and then the DNA was air dried and resuspended in TE buffer.

\section{Restriction analysis of phage DNA}

The Phage DNA isolates were digested with restriction enzymes using a standard restriction digestion assay (32) as per the manufacturer's instructions (Fermentas). Of the five enzymes tested (Eco RI, Hind III, Nhe I, Kpn I and Alu I) two were selected (Eco RI, Hind III) based on the observation of clear multiple bands on agarose gels. The restriction digests were electrophoresed on $0.8 \%$ agarose gels in $1 \mathrm{X}$ TAE buffer stained with ethidium bromide and visualized by UV photography. The phage genome sizes were determined by using semi-log plotting method where, a logarithmic scale is used to graph the results in semi-log paper. (11). Restriction digested samples run on the agarose gel along with the $1 \mathrm{~kb}$ ladder marker was used for semi-log plotting. The sum of the size of the bands present in each sample is the approximate size of the bacteriophage genome.

\section{SDS-PAGE analysis of phage proteins}

Phage structural proteins were analyzed by sodium 
dodecyl sulfate-polyacrylamide gel electrophoresis (SDS PAGE) as described by Laemmli (20). Samples were heated at $95^{\circ} \mathrm{C}$ for $15 \mathrm{~min}$ and subjected to electrophoresis with a $10 \%$ polyacrylamide gel at $150 \mathrm{~V}$ for $2 \mathrm{hrs}$. Proteins were visualized on gels stained with silver nitrate (7).

\section{AFM analysis}

The sample was prepared as described by Archer et al., (4). The virus particles were deposited for adsorption on preliminary cleaned, glass cover slips. After adsorption of the phage particles onto the surface, the substrates were allowed to dry at room temperature and then carefully rinsed with Milli-Q water. Imaging was performed using NTMDT-Atomic Force Microscopy.

\section{RESULTS}

A total of 15 fluorescent bacteria were isolated from both soil and sewage samples. Each soil sample was enriched with soil isolates as their isolation host. Plaques were observed only with phage lysates obtained from sewage. In total, 7 lytic phages were isolated from sewage enrichment process. They were selected based on their size and morphology of the plaques. The size and plaques produced by the isolated phages in all three months are listed in Table 1. The bacteriophage load on both inlet and outlet of sewage treatment plant was also assessed. Ninety percent of bacteriophage reduction was found in outlet sample (data not shown).

The susceptibility of the bacterial isolates to infection by 7 phages was examined. All the 7 phages isolated, individually lysed the sewage bacterial isolates Pfsw-13 and Pfsw-15 by the spot test method. Phage \#5 showed lytic activity against several fluorescent isolates and also against $P$. aeruginosa MTCC 2474 standard strain. The susceptibility of the bacterial isolates to these phages is shown in Table 2.

Table 1. Morphology and size of the plaques

\begin{tabular}{llll}
\hline $\begin{array}{c}\text { Phage isolates } \\
\text { from sewage }\end{array}$ & $\begin{array}{l}\text { Plaque size } \\
(\mathbf{m m} \text { dia) }\end{array}$ & $\begin{array}{l}\text { Plaque } \\
\text { morphology }\end{array}$ & PFU/ml \\
\hline$\# 1$ & $2 \mathrm{~mm}$ & clear & $5.6 \times 10^{7}$ \\
$\# 2$ & $5 \mathrm{~mm}$ & turbid & $3.6 \times 10^{7}$ \\
$\# 3$ & $3 \mathrm{~mm}$ & turbid & $2.3 \times 10^{7}$ \\
$\# 4$ & $1 \mathrm{~mm}$ & clear & $3.2 \times 10^{7}$ \\
$\# 5$ & $2 \mathrm{~mm}$ & clear & $5.9 \times 10^{7}$ \\
$\# 6$ & $2 \mathrm{~mm}$ & clear & $1.4 \times 10^{7}$ \\
$\# 7$ & $1 \mathrm{~mm}$ & clear & $3.2 \times 10^{7}$ \\
\hline
\end{tabular}

Table 2. Bacterial susceptibility to Pseudomonas phages

\begin{tabular}{|c|c|c|c|c|c|c|c|c|}
\hline \multirow[t]{2}{*}{ HOST } & \multirow[t]{2}{*}{ SOURCE } & \multicolumn{7}{|c|}{ PHAGE ISOLATES } \\
\hline & & $\# 1$ & $\# 2$ & $\# 3$ & $\# 4$ & $\# 5$ & $\# 6$ & $\# 7$ \\
\hline Pfsw-13 & Sewage treatment plant & $\mathrm{S}$ & $\mathrm{S}$ & $\mathrm{S}$ & $\mathrm{S}$ & $\mathrm{S}$ & $\mathrm{S}$ & $\mathrm{S}$ \\
\hline Pfsw-14 & Sewage treatment plant & $\mathrm{R}$ & $\mathrm{R}$ & $\mathrm{R}$ & $\mathrm{R}$ & $\mathrm{R}$ & $\mathrm{R}$ & $\mathrm{R}$ \\
\hline Pfsw-15 & Sewage treatment plant & $S$ & $\mathrm{~S}$ & $\mathrm{~S}$ & $S$ & $\mathrm{~S}$ & $\mathrm{~S}$ & $\mathrm{~S}$ \\
\hline P.fluorescens & Reference strain & $S$ & $\mathrm{R}$ & $\mathrm{S}$ & S & $\mathrm{S}$ & $\mathrm{R}$ & $\mathrm{S}$ \\
\hline P.aeruginosa & Reference strain & $\mathrm{R}$ & $\mathrm{S}$ & $\mathrm{R}$ & $\mathrm{R}$ & $\mathrm{S}$ & $\mathrm{S}$ & $\mathrm{R}$ \\
\hline
\end{tabular}

(R- resistant, S- susceptible) 


\section{Genome fingerprinting analysis}

The DNA isolated from all the phages were double stranded and were sensitive to EcoRI and Hind III. Figure 1 shows the restriction pattern of the phage DNA. The estimated genome sizes ranged from 26 to $82 \mathrm{~Kb}$. The genome size of each phage isolates was found to be similar when tested by the two enzymes used. The genome fingerprint of the phage DNA shows the diversity among the phage isolates.

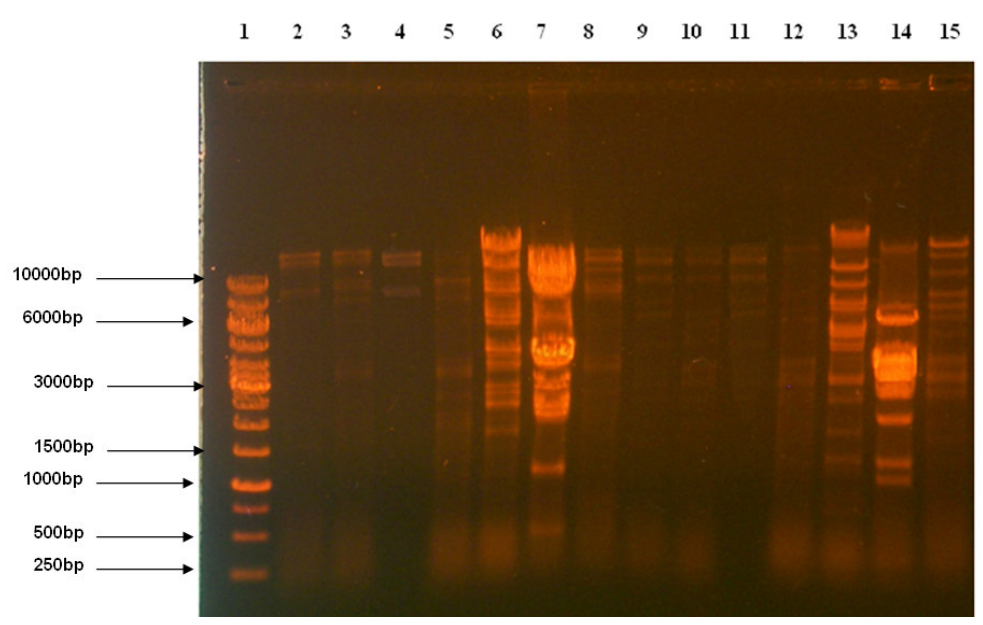

Figure 1. Restriction profile of the isolated bacteriophage DNA

Lane 1- $1 \mathrm{~Kb}$ ladder

Lane 2- 8: EcoRI digestion of the phage DNA

Lane 9-15: HindIII digestion of phage DNA samples

(Phage \#1 to \#7 respectively)

\section{Analysis of phage proteins}

Phage lysates were examined using SDS-PAGE, stained with silver nitrate. Multiple bands were present in each of the lysates. At least 5 bands can be clearly distinguished in the gel

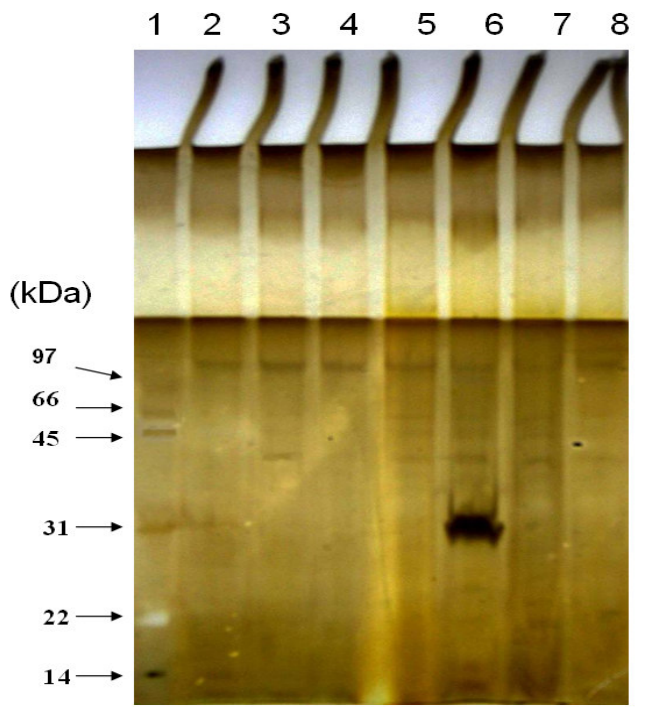

ranging from approximately $97 \mathrm{kDa}$ to $14 \mathrm{kDa}$ (Figure 2). Phage \#5 isolate has a distinct band at a size of approximately $35 \mathrm{kDa}$ with high concentration.

Figure 2. Protein profile of the bacteriophages on SDS PAGE, stained with silver nitrate Lane 1: Standard protein marker Lane 2-8: Whole cell protein of the bacteriophage isolates 


\section{AFM analysis}

Fig 3 shows atomic force microscopy topological images of bacteriophage particles on aminosilanized glass. Phage size measurements were performed directly on micrographs at $1 \mu \mathrm{m}$ magnification. According to the head diameter, viral particles were classified into three size classes $(>=85 \mathrm{~nm},>40 \mathrm{~nm}$ and $<$ $15 \mathrm{~nm})$. Bacteriophages could not be clearly differentiated according to their fine structures.

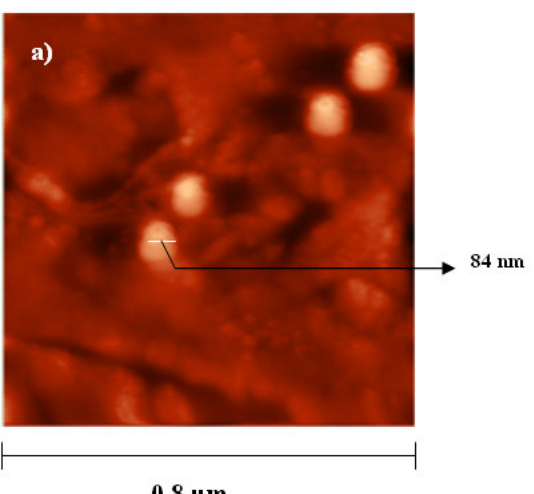

$0.8 \mu \mathrm{m}$

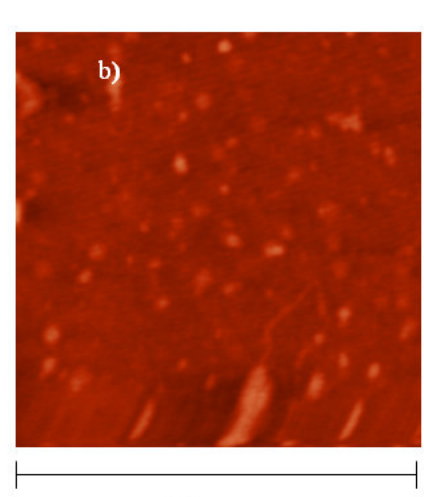

$0.8 \mu \mathrm{m}$

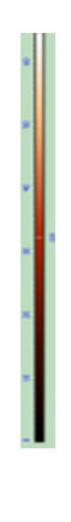

$60 \mathrm{~nm}$

Figure 3. Atomic force microscopy images of bacteriophages

a) Morphology of phage \#5, b) morphology of phage \#1.

\section{DISCUSSION}

Seven phages were isolated from sewage enrichment process, whereas isolation of phages from soil samples was found to be unsuccessful. The results are in concordance with an earlier study wherein the phages of Pseudomonas were successfully isolated only from water samples, while in soil and feces no Pseudomonas specific phages were detected (22).Earlier studies attribute similar results to relatively low viable counts of phage capable of infecting specific bacteria (6), relatively low rates of phage diffusion within soil, particularly under drier conditions (18) and relatively high rates of free-phage inactivation within soil (27). There have been a number of reports of phage presence, in various environments $(14,2)$. However, it is uncertain how those phages from sewage have impact on bacterial populations in soil environment. The susceptibility analysis of soil bacterial isolates in this study shows the soil bacterial population was resistant to these phage isolates. It is interesting to note that soil bacterial isolates obtained within the vicinity of sewage treatment plant showed resistance to the phages isolated from sewage. Each of the 7 phages was able to individually lyse the isolation host. None of the $P$. fluorescens bacteria isolated from the cultivated soils were susceptible to seven phages. In one study, phages of human enteric bacteria were also reported to be associated with plants displaying broad host range (29). Similarly, phage infecting phytopathogenic Pseudomonas have been isolated from sewage $(21,36)$ while Agrobacterium-infecting phage have been isolated from feces $(25,31)$. But from our study, it was found that the bacteriophage having broad host range activity isolated from sewage environment showed no lytic activity among cultivated soil isolates. However, further studies need to be carried out to understand the impact on natural bacterial population of cultivated soils. The phage \#5 in our study was able to completely lyse the host bacterium $P$. fluorescens and $P$. aeruginosa. This indicated the broad range of host specificity of the bacteriophage. Broad host range phages play a key role in phage ecology and gene transfer in nature (14). The restriction pattern of the phage DNA shows the genomic diversity among the isolates. All the phages 
isolated were double stranded and sensitive to EcoRI and HindIII (Figure 1). The restriction analysis indicated that the phages were genetically distinct. The phage \#6 has a genome size of about $37 \mathrm{~kb}$ which is very close to the $P$. aeruginosa phage MP22 (12) and also phage \#2 has approximately $58 \mathrm{~kb}$ genome size, similar to D3 phage which is a $P$. aeruginosa phage (19). The host range of these two phages also suggests that they are lytic against $P$. aeruginosa (Table 1). The phage \#5 has a genome size of about $80 \mathrm{~kb}$, which showed broad range host specificity and did not have match to any sequences of the phage genome databases. A major protein with the same molecular weight (above $97 \mathrm{kDa}$ ) was present in all the seven phages analyzed, which is consistent with the results obtained by Alonso et al., (2). It suggested that the molecular weights of the major proteins do not vary among phage lysates specific to the same bacterial strains. The morphological feature of the phage \#5 was also different from other six phage isolates. The average size of the capsid for bacteriophage \#5 was approximately $84 \mathrm{~nm}$. This phage has morphological characteristics somewhat similar to T4 bacteriophage (4). However, the fine structure like tail length was not observed. The ecological importance of this phage must be further studied. Though only representative part of the Pseudomonas phages was investigated, a great variability has been observed.

\section{REFERENCES}

1. Ackermann, H.W. (2001). Frequency of morphological phage descriptions in the year 2000. Arch. Virol., 146; 843-857.

2. Alonso, M.D.; Rodriguez J.; Borrego J.J. (2002). Characterization of marine bacteriophages isolated from the Alboran Sea; Western Mediterranean. J. Plankton Res., 24; 1079-1087.

3. Armon, R.; Kott, Y. (1993). A simple, rapid and sensitive presence/ absence detection test for bacteriophage in drinking water. J. Appl. Bact., $74 ; 490-496$.

4. Archer, J.M.; Jinny, L. Liu. (2009). Bacteriophage T4 Nanoparticles as Materials in Sensor Applications: Variables That Influence Their Organization and Assembly on Surfaces' Sensors. 9(8); 6298-6311.

5. Ashelford, K.E.; Day, M.J.; Bailey, M.J.; Lilley, A.K.; Fry, J.C. (1999). In situ population dynamics of bacterial viruses in a terrestrial environment. Appl. Environ. Microbiol., 65; 169-174.
6. Ashelford, K. E.; Day, M. J.; Fry, J. C. (2003). Elevated abundance of bacteriophage infecting bacteria in soil. Appl. Environ. Microbiol., 69; 285-289.

7. Bassom B.J.; Caetano-Annolles G.; Gresshoff P.M. (1991). Fast and sensitive silver staining of DNA in polyacrylamide gels, Analytical Biochemistry, 196; 80-83.

8. Brazil G.M.; Kenefick L.; Callanan M.; Haro A.; de Lorenzo V.; Dowling D.N.; O'Gara F. (1995). Construction of a rhizosphere Pseudomonad with potential to degrade polychlorinated biphenyls and detection of bph gene expression in the rhizosphere, Appl. Environ. Microbiol., 61;1946-1952.

9. Campbell, J.I.A.; Albrechtsen, M.; Sorensen, J. (1995). Large Pseudomonas phages isolated from barley rhizosphere. FEMS (Fed. Eur. Microbiol. Soc.) Microbiol. Ecol., 18; 63-74.

10. Dobrindt, U.; Reidl J. (2000). Pathogenicity islands and phage conversion: evolutionary aspects of bacterial pathogenesis. Int J Med Microbiol., 6; 519-27.

11. Dooley, M. (2007). Restriction Endonuclease Digestion of a Plasmid, Association for Biology Laboratory Education Proceedings, 29; 389-392

12. Goszczynska, T.; Serfontein, J.J.; Serfontein, S. (2000). Introduction to Practical Phytobacteriology. Bacterial Disease Unit. ARC-Plant Protection Research Institute Pretoria. South Africa.

13. Heo, Y.J.; Chung, I.Y.; Choi, K.B.; Lau, G.W.; Cho, Y.H. (2007). Genome sequence comparison and superinfection between two related Pseudomonas aeruginosa phages, D3112 and MP22. Microbiology., 1531; 2885-2895.

14. Jensen, C.E.; Schrader S.H.; Rieland B.; Thompson T.L.; Lee K.W.; Nickerson K.W.; Kokjohn T.A. (1998). Prevalence of Broad Host Range lytic Bacteriophages of Sphaerotilus natans, Escherichia coli and Pseudomonas aeruginosa. Appl.Environ. Microbiol., 64(2); 333-340.

15. Joas, L.; Da Silva.; Rosario D.C. Hirata.; Mario H. Hirata. (2009). Bacteriophage: laboratorial diagnosis and phage therapy Braz. J. Microbiol., 40 (3).

16. Jonathan, M.B. (2003). Phage Isolation and Investigation Dartmouth Undergraduate. J. of Science., 3(1).

17. Karlson, U.; Dowling, D.; O’Gara, F.; Rivilla, R.; Bittens, M.; Francesconi, S.; Pritchard, H.;Pedersen, H.C. (1998). Development of self-contained plant/GMM systems for soilbioremediation, In de Vries G.E. (ed.), Past, present and future risk assessment when using GMOs, Overschild, The Netherlands, 23.

18. Knezevic, P.; Kostanjsek, R.; Obreht, D.; Petrovic, O. (2009). Isolation of Pseudomonas aeruginosa specific phages with broad activity spectra. Curr Microbiol., 59; 173-80.

19. Kwan, T.; Liu, J.; DuBow, M.; Gros, P.; Pelletier, J. (2006). Comparative Genomic Analysis of 18 Pseudomonas aeruginosa Bacteriophages. Journal of Bacteriology. 188(3); 1184-1187.

20. Laemmli, U.K. (1970) Cleavage of structural proteins during the 
assembly of the head of bacteriophage T4. Nature, 227; 680-685.

21. Lee, I. F.; Boezi, J. A. (1966). Characterisation of bacteriophage gh- 1 for Pseudomonas putida. J.Bacteriol., 92; 1821-1827.

22. Lu, Z.; Breidt, F.; Plengvidhya, V.; Fleming, H.P. (2003). Bacteriophage ecology in commercial sauerkraut fermentations. Appl. Environ. Microbiol., 3192-3202.

23. Miao, E.A.; Miller, S.I. (1999). Bacteriophages in the evolution of pathogen-host interactions. Proc. Natl. Acad. Sci. USA, 96; 9452-9454.

24. Nourozian J.; Etebarian H.R.; Khodakaramian G. (2006). Biological control of Fusarium graminearum on wheat by antagonistic bacteria. Journal of Science and Technology, 28; 29-38.

25. Okabe, N.; Goto, M. (1963). Bacteriophages of plant pathogens. Ann. Rev. Phytopathol., 1; 397-418.

26. O'Sullivan, D.J.; O'Gara, F. (1992). Traits of fluorescent Pseudomonas spp. involved in suppression of plant root pathogens. Microbiol. Mol. Biol. Rev.,56 (4); 662-676.

27. Pantastica, C.M.; Duncan, K. E.; Istock, C. A.; Bell, J. A. (1992). Population dynamics of bacteriophage and Bacillus subtilis in soil. Ecology. 73; 1888-1902.

28. Pickett, M.J.; Goodneer, J.R.; Harvey, S.M. (1991). Test for detecting degradation of gelatin: Comparison of five methods. J. Clinical Microbiol., 29; 2322-2325.
29. Pirhonen, M.; Palva, E. T. (1988). Occurence of bacteriophage T4 receptor in Erwinia carotovora. Mol. Gen. Genet., 214; 170-172.

30. Prescott, L.M.; Harley, J.P. (1993). Laboratory Exercises in Microbiology. $2^{\text {nd }}$ edition. Chapters 58 and 59.

31. Roslycky, E. B. (1962). Phages for Agrobacterium radiobacter with reference to host range. Can. J. Microbiol., 8; 71-78.

32. Sambrook, J.; Maniatis, T.; Fritsch E.F. (1989). Molecular Cloning: A Laboratory Manual, $2^{\text {nd }}$ edition, Cold Spring Harbor Laboratory Press, Cold Spring Harbor, NY.

33. Scott, C.A.; Faruqui, N.I.; Raschid-Sally, L. (2004) Wastewater use in irrigated agriculture: confronting the livelihood and environmental realities. Wallingford: Cabi Publishing, 1-10.

34. Sillankorva, S.; Neubauer P.; Azeredo J. (2008). Isolation and characterization of a T7-like lytic phage for Pseudomonas fluorescens, BMC Biotechnology, 8(80).

35. Smith, H.W.; Huggins, M.B. (1982). Successful treatment of experimental Escherichia coli infections in mice using phage: its general superiority over antibiotics, Journal of General Microbiology, 128; 307318.

36. Thomas, M.D.; Leary, J.V. (1983). Bacteriophages from sewage specific for fluorescent phytopathogenic pseudomonads. Phytopathology, 73; 403-406. 